\title{
PREVALENCE OF NON-ALCOHOLIC FATTY LIVER DISEASE IN WOMEN WITH POLYCYSTIC OVARY SYNDROME AND ITS CORRELATION WITH METABOLIC SYNDROME
}

\author{
Mariana Drechmer ROMANOWSKI, Monica Beatriz PAROLIN, Alexandre C T FREITAS, \\ Mauri J PIAZZA, Jorgete BASSO and Almir A URBANETZ
}

\begin{abstract}
Background - The polycystic ovary syndrome (PCOS) is one of the most common endocrine disorders in women at childbearing age. Metabolic syndrome is present from $28 \%$ to $46 \%$ of patients with PCOS. Non-alcoholic fatty liver disease (NAFLD) is considered the hepatic expression of metabolic syndrome. There are few published studies that correlate PCOS and NAFLD. Objective - To determine the prevalence of NAFLD and metabolic syndrome in patients with PCOS, and to verify if there is a correlation between NAFLD and metabolic syndrome in this population. Methods - Study developed at Gynecology Department of Clinical Hospital of Federal University of Parana (UFPR). The sessions were conducted from April 2008 to January 2009. One hundred and thirty-one patients joined the analysis; 101 were diagnosed with PCOS and 30 formed the control group. We subdivided the PCOS patients into two subgroups: PCOS+NAFLD and PCOS. All the patients were submitted to hepatic sonography. For hepatoestheatosis screening, hepatic ecotexture was compared do spleen's. For diagnosis of metabolic syndrome, we adopted the National Cholesterol Education Program/Adult Treatment Panel III (NCEP/ATP III) criteria, as well as the criteria proposed by International Diabetes Federation. Statistical analysis were performed with $t$ of student and U of Mann-Whitney test for means and chi square for proportions. Results - At PCOS group, NAFLD was present in $23.8 \%$ of the population. At control group, it represented 3.3\%, with statistical significance $(P=0.01)$. Metabolic syndrome, by NCEP/ATP III criteria, was diagnosed in $32.7 \%$ of the women with PCOS and in $26.6 \%$ of the women at control group (no statistical difference, $P=0.5$ ). At PCOS+DHGNA subgroup, age, weight, BMI, abdominal circumference and glucose tolerance test results were higher when compared to PCOS group $(P<0.01)$. Metabolic syndrome by NCEP/ATPIII criteria was present in $75 \%$ and by International Diabetes Federation criteria in $95.8 \%$ of women with PCOS+NAFLD with $P<0.01$. Insulin levels at SOP+DHGNA were higher than at PCOS group with $P<0.01$. Conclusion - Almost 25\% of the patients with PCOS were diagnosed for NAFLD. Metabolic syndrome was present between $32.7 \%$ and $44.6 \%$ of patients with PCOS. At subgroup PCOS+NAFLD, metabolic syndrome is highly prevalent. These patients are more obese, with higher BMI and higher glucose levels.
\end{abstract}

HEADINGS - Polycystic ovary syndrome. Fatty liver. Metabolic syndrome X.

\section{INTRODUCTION}

The polycystic ovary syndrome (PCOS) is one of the most common endocrine disorders, affecting from $5 \%$ to $11 \%$ of women at childbearing age $e^{(1,2,3,9,10)}$. The classically PCOS is characterized by irregular menstrual cycles (oligomenorrhea) and evidence of clinical and/or laboratorial hyperandrogenism with hirsutism, acne, androgenic pattern of alopecia and ultrasound findings of polycystic ovaries, in the absence of other medical conditions coursing with androgen excess (hyperprolactinemia, non classical congenital adrenal hyperplasia, Cushing syndrome, androgen-producing neoplasm and acromegaly).

Although in its most typical form PCOS course with hyperandrogenism and chronic anovulation, diagnostic criteria recently proposed ${ }^{(11,12)}$ consider that PCOS can be found in patients with ovulatory cycles but having hyperandrogenism (clinical or biological) and polycystic ovaries ${ }^{(11,12)}$ and in patients with chronic anovulation, polycystic ovaries but without excess of androgens ${ }^{(12)}$, as it is observed in Figure 1. 


\section{Diagnostic criteria for PCOS proposed by the androgen excess society guidelines ${ }^{(12)}$ :}

\section{Clinical or biological hyperandrogenism}

Clinical: hirsutism, acne, androgenic alopecia

Biological: increase of serum testosterone or the index of

free androgen or dehydroepiandrosterone sulfate

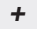

\section{Chronic anovulation}

Oligomenorrhea or amenorrhea or monthly cycles but with low serum levels of progesterone on the days 22 to 24 of the cycle

\section{or}

Polycystic ovaries on ultrasound (ESHRE/ASRM - 2004) ${ }^{(19)}$

Finding of at least 12 follicles of $2-9 \mathrm{~mm}$ in an ovary

and/or increase of ovarian volume

FIGURE 1. Diagnostic criteria for PCOS.

The association of PCOS with insulin resistance state, resulting in effects on reproductive, metabolic and cardiovascular health of affected patients, rekindled interest of the scientific community about this endocrine condition since it identifies a subgroup of individuals who deserves a broader and deeper approach than just the (a) treatment of the most common events as hirsutism, acne and oligomenorrhea ${ }^{(2)}$.

Insulin plays direct and indirect roles in the pathogenesis of hyperandrogenism in women with PCOS. It acts synergistically with the luteinizing hormone (LH) increasing the androgen synthesis by ovarian theca cells. In addition, insulin inhibits the steroid hormone binding globulin (SHBG) synthesis by the liver, increasing the amount of free and biologically active testosterone in the circulation. Since patients with PCOS usually have hyperinsulinemia, the concentration of free testosterone is increased even if the total amount of testosterone is within the upper limit of normality or modestly elevated ${ }^{(2)}$.

Because insulin resistance is one of the pathophysiologic bases of metabolic syndrome, patients with PCOS and high levels of plasmatic insulin have a substantial risk of developing metabolic and cardiovascular complications such as obesity, glucose intolerance and type 2 diabetes, dyslipidemia, and coronary heart disease ${ }^{(26)}$. In fact, several studies point to a higher frequency of metabolic syndrome (MS) or some of its components alone in women with PCOS when compared to the normal population ${ }^{(6,13-17)}$ Marcondes et al. ${ }^{(19)}$ published a retrospective study on the MS prevalence in women with PCOS who were followed at Hospital de Clínicas at University of São Paulo, which found high levels (about 38\%), when the modified criteria of NCET ATP III recommended by ESHRE/ASRM-PCOS, Consensus Workshop Group ${ }^{(19)}$ is applied.

In fact, the current approach of patients with PCOS should necessarily include screening for MS risk factors. The American College of Cardiology recommends that women with PCOS should be evaluated for possible metabolic disorders, including performing fasting and 2 hours postprandial glucose (Oral Glucose Tolerance Test or OGTT), basal insulin levels, glycosylated hemoglobin and lipids levels ${ }^{(19)}$. OGTT is the most sensitive method to detect glucose intolerance in women with $\operatorname{PCOS}^{(28)}$.

Similar as happens in PCOS and MS, insulin resistance also emerges on the pathogenesis basis of non-alcoholic fatty liver disease (NAFLD), the most common form of liver disease nowadays ${ }^{(5)}$. Thus, insulin resistant patients have a greater risk of developing NAFLD ${ }^{(10)}$ Due to the evolutionary potential of NAFLD, particularly in individuals with metabolic syndrome, early diagnostic and therapeutic intervention are of great value for such patients ${ }^{(18)}$.

The gold standard for the diagnosis of NAFLD is liver biopsy, but this method presents some limitations such as sampling variability (heterogeneous parenchymal involvement), higher cost and complication risks because it is an invasive procedure. Liver function tests (serum samples) may show up within normal limits or have a fluctuating course in NAFLD patients. In fact, severe forms of NAFLD have already been described in patients with normal enzymes. Imaging methods such as ultrasound can detect the presence of steatosis but without quantifying the degree of inflammatory activity or evaluate the level of eventual fibrosis. The ultrasound lacks sensibility in cases in which the amounts of fat deposited are under $30 \%$. But, because it is a faster, cheaper and non-invasive method, ultrasound has been used in many epidemiological studies and also in medical practice ${ }^{(8)}$. Magnetic resonance imaging (MRI), even though more sensitive in detection and quantification of steatosis, is quite more expensive, what restricts its applicability as a screening test ${ }^{(4)}$.

Deepest knowledge of PCOS pathophysiology shows its systemic repercussions, associated to considerable morbidity, what requires special attention from the medical team and multidisciplinary approach. Although metabolic evaluation of these patients is already a routine, compilation of such data will be valuable to profile the metabolic complications of PCOS in Brazilian women, whose genetic background and life habits are distinct from the population already studied.

\section{METHODS}

Prospective study was developed to determine the prevalence of NAFLD and MS in adult women with PCOS. Patients came from the Endocrine Gynecology Clinic at Clínicas Hospital at UFPR. Sessions were conducted from April 2008 to January 2009 and during this period 137 patients were included in the study, among women with PCOS $(n=103)$ and controls $(n=34)$. Study design was approved by the Department of Gynecology of Clínicas Hospital at UFPR and by the Ethic Committee in Research in Humans at the same institution. 


\section{Inclusion criteria}

Women aged $\geq 18$ years old with confirmed diagnosis of PCOS based on criteria established by the Androgen Excess Society Guidelines ${ }^{(12)}$, not using hormonal contraception for at least 3 months, were included. Patients who met at least one of the following criteria were excluded:

a) previous history of chronic liver disease;

b) suffering from conditions that can occur with known liver enzyme abnormalities;

c) using medication that are risk factors for NAFLD such as corticosteroids, tamoxifen, amiodarone, diltiazem, protease inhibitors (ARVs);

d) using metformin for hirsutism because it may interfere in blood glucose levels;

e) daily consumption of ethanol $\geq 20$ grams;

f) failure to agree in participating in the study.

Control group was formed by women that spontaneously looked for medical care with symptoms of irregular menstrual cycles, infertility, hisutism, acne, or problems trying to lose weight, but did not have the criteria for PCOS.

\section{Protocol}

All included patients were submitted to anamnesis and physical examination to collect the following variables (see data collection sheet):

a) age, menstrual pattern, a history of arterial hypertension treatment, family history of diabetes treatment, history of dyslipidemia treatment;

b) race, weight, height $(\mathrm{cm})$, waist circumference $(\mathrm{cm})$, presence of acne, hirsutism, androgenic alopecia, acanthosis nigricans (indirect sign of insulin resistance) and systemic arterial pressure in the supine position (after 20 minutes of rest).

Regarding the already established PCOS diagnosis, following data were collected from medical records: pattern of menstrual cycles; ultrasonographic findings in ovaries; testosterone serum level; free androgen level; dehydroepiandrosterone sulfate level; evidence of exclusion of other causes of menstrual cycles irregularities or excess of androgen including hyperprolactinemia, non-controlled thyroid disease, congenital adrenal hyperplasia, premature ovarian failure, Cushing's syndrome, androgen-secreting tumor or pregnancy.

After the interview, the patients were requested to take a sonogram of the right hypochondrium with one of the researchers (all the sonograms were conducted by researcher Basso), and to collect the following laboratory exams after 12 hours of fasting:

a) Glucose tolerance test (glucose fasting and 2 hours post-load of 75 grams of glucose orally, in $\mathrm{mg} / \mathrm{dL}$ );

b) Triglycerides $(\mathrm{mg} / \mathrm{dL})$, total cholesterol and HDL cholesterol $(\mathrm{mg} / \mathrm{dL})$, basal insulin $(\mu \mathrm{UI} / \mathrm{mL})$, alanine aminotransferase (ALT, UI/L).

BMI was calculated according to formula: weight $(\mathrm{Kg}) /$ height $(\mathrm{cm})^{2}$. To measure the waist circumference, patient was placed in the supine position and measuring tape put parallel to the ground positioned at the top of the iliac crest, at the end of the normal expiration movement ${ }^{(21)}$
HOMA-IR method was used to determine insulin resistance. It is calculated according to the formula below ${ }^{(22)}$. HOMA-IR values above 1,5 are indicative of insulin resistance.

HOMA-IR $=\frac{\text { glucose fasting }(\mathrm{mg} / \mathrm{dL}) \times \text { basal insulin }(\mu \mathrm{UI} / \mathrm{mL})}{405}$

For the diagnosis of MS, the following criteria were used: a) Criteria proposed by the National Cholesterol Education Program/Adult Treatment Panel III (NCEP/ ATP III) and adapted for use in patients with PCOS by the Rotterdam ESHRE/ASRM-Sponsored PCOS Consensus Workshop ${ }^{(20)}$. Presence of at least 3 of the criteria bellow:

- Waist circumference $>88 \mathrm{~cm}$;

- Fasting glucose $\geq 110 \mathrm{mg} / \mathrm{dL}$ or

- Glucose 2 hours after overload $\geq 140 \mathrm{mg} / \mathrm{dL}$ (oral glucose tolerance test);

- Fasting triglycerides $\geq 150 \mathrm{mg} / \mathrm{dL}$;

- HDL cholesterol <50 mg/dL;

- Blood pressure $\geq 130 / 85 \mathrm{mmHg}$.

b) Criteria proposed by the International Diabetes Federation (IDF) ${ }^{(23,27)}$, which reduce threshold values for fasting glucose $(\geq 100 \mathrm{mg} / / \mathrm{dL})$ and for the waist circumference $(>80 \mathrm{~cm}$ for Asian and South American women) associated with the proposal by the American Heart Association/National Heart, Lung, and Blood Institute Criteria for Diagnosis of the Metabolic Syndrome ${ }^{(21)}$, where the criterion of hypertension is achieved by the presence of systolic $\mathrm{BP} \geq 130$ and/or diastolic $\mathrm{BP} \geq 80 \mathrm{mmHg}$, and the triglycerides, HDL-c and PA are considered abnormal in patients who are on medication to control these factors. Presence of at least three of the criteria below:

- Waist circumference $>80 \mathrm{~cm}$;

- Fasting glucose $\geq 100 \mathrm{mg} / \mathrm{dL}$ or on treatment for hyperglycemia;

- Fasting triglycerides $\geq 150 \mathrm{mg} / \mathrm{dL}$ or on treatment for hypertriglyceridemia;

- HDL cholesterol $<50 \mathrm{mg} / \mathrm{dL}$ or on treatment for reduced HDL-c;

- Systolic blood pressure $\geq 130 \mathrm{mmHg}$ and/or diastolic $\geq 85 \mathrm{mmHg}$ or history of hypertension and in use of antihypertensive;

\section{Ultrasound diagnosis of NAFLD}

All patients were submitted to ultrasonography of the liver with $3.5 \mathrm{MHz}$ convex transducer. For the screening for hepatic steatosis, hepatic parenchymal echo texture was evaluated and compared with the echo texture of the spleen. When isoechogenic, the liver parenchyma is considered normal, that is, without evidence of steatosis. The presence of hyperechoic hepatic parenchyma (bright liver) is considered a characteristic of hepatic steatosis ${ }^{(24)}$. The presence of steatosis was classified in: 
- Level I (mild) when there is a diffuse increase of fine echoes in the liver parenchyma but allows good view of the vessel walls;

- Level II (moderate) when diffuse increase of the echogenicity liver parenchyma difficult the view of the vascular walls and diaphragm;

- Level III (severe) when there is a significant increase of the fine echoes and intense posterior attenuation preventing the view of the vascular walls and diaphragm.

\section{RESULTS}

Two hundred and nine women attended the Gynecology outpatient at HC/UFPR for screening of PCOS, MS and
NAFLD. Of these, 101 were diagnosed with PCOS, 30 had other diagnoses, such as premature ovarian failure and hypothyroidism, 2 only presented clinical hyperandrogenism, without other criteria for PCOS. Seventy-six women were excluded from the study because they were outside the age range provided in the methods $(n=2)$, because pregnancy was diagnosed $(n=4)$, because they were using hormonal contraception and have not quitted it to enable the laboratory assays $(n=25)$, or because they quit attendance to the meetings $(n=45)$. These results are seen in Figure 2.

The patients were first divided into PCOS group and control group. These groups were compared in various criteria as shown on Table 1. It is observed that patients with PCOS, even younger than the patients from the control

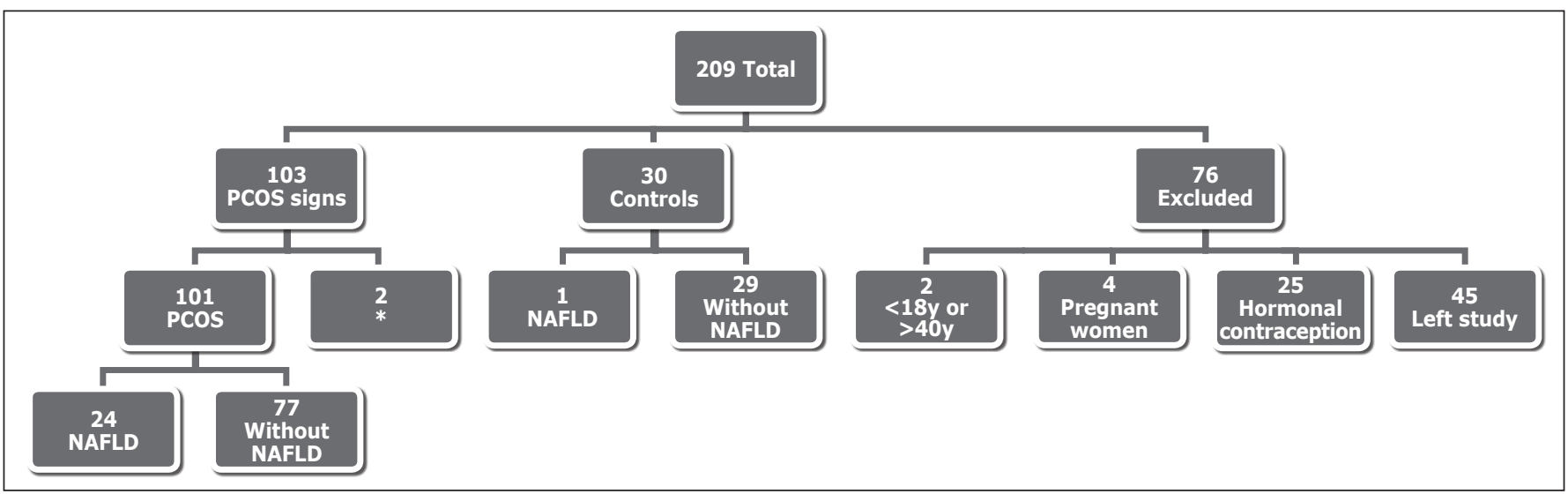

FIGURE 2. Distribution of women treated according with PCOS diagnosis, exclusion criteria and no follow-up PCOS: polycystic ovary syndrome; NAFLD: non-alcoholic faty liver disease. *Only clinical hyperadrogenism.

TABLE 1. Comparison between patients with polycystic ovary syndrome group and control group

\begin{tabular}{|c|c|c|c|}
\hline & Group SOP $(n=101)$ & Control group $(n=30)$ & $P$ \\
\hline Age (years) $\pm \mathrm{DP}$ & $26.8 \pm 5$ & $33.7 \pm 7$ & 0.01 \\
\hline Weight $(\mathrm{kg}) \pm \mathrm{DP}$ & $74 \pm 20$ & $67.5 \pm 13$ & 0.03 \\
\hline $\mathrm{BMI}\left(\mathrm{kg} / \mathrm{m}^{2}\right) \pm \mathrm{DP}$ & $28.5 \pm 6$ & $26.1 \pm 4$ & 0.02 \\
\hline Waist circumference $(\mathrm{cm}) \pm \mathrm{DP}$ & $91.6 \pm 16$ & $86.4 \pm 12$ & 0.05 \\
\hline \multicolumn{4}{|l|}{ Oral glucose tolerance test } \\
\hline Fasting glucose $(\mathrm{mg} / \mathrm{dL}) \pm \mathrm{DP}$ & $95.6 \pm 8$ & $97.6 \pm 8$ & 0.2 \\
\hline Blood glucose after 2 hours $(\mathrm{mg} / \mathrm{dL}) \pm \mathrm{DP}$ & $109.8 \pm 28$ & $107.3 \pm 21$ & 0.6 \\
\hline Area under the curve OGTT & $1335.9 \pm 216$ & $1332.2 \pm 169$ & 0.7 \\
\hline Triglycerides $(\mathrm{mg} / \mathrm{dL}) \pm \mathrm{DP}$ & $103.3 \pm 60$ & $101.7 \pm 41$ & 0.8 \\
\hline $\mathrm{HDL}(\mathrm{mg} / \mathrm{dL}) \pm \mathrm{DP}$ & $45.6 \pm 11$ & $49.9 \pm 10$ & 0.05 \\
\hline $\mathrm{SBP}(\mathrm{mmHg}) \pm \mathrm{DP}$ & $116 \pm 13$ & $114 \pm 13$ & 0.6 \\
\hline $\mathrm{SBP}(\mathrm{mmHg}) \pm \mathrm{DP}$ & $74 \pm 12$ & $72 \pm 12$ & 0.3 \\
\hline $\operatorname{MAP}(\mathrm{mmHg}) \pm \mathrm{DP}$ & $129.6 \pm 15$ & $128.7 \pm 14$ & 0.7 \\
\hline Insulin $(\mu \mathrm{UI} / \mathrm{mL}) \pm \mathrm{DP}$ & $12.2 \pm 10$ & $8 \pm 7$ & 0.02 \\
\hline $\mathrm{HOMA} \pm \mathrm{DP}$ & $2.9 \pm 2$ & $2 \pm 2$ & 0.03 \\
\hline \multicolumn{4}{|l|}{ Metabolic syndrome (NCEP/ATP III criterion) } \\
\hline Present $\mathrm{n}(\%)$ & $33(32.7 \%)$ & $8(26.6 \%)$ & 0.5 \\
\hline Absent n (\%) & $68(67.3 \%)$ & $22(73.4 \%)$ & \\
\hline \multicolumn{4}{|l|}{ Metabolic syndrome } \\
\hline Present $\mathrm{n}(\%)$ & $45(44.6 \%)$ & $11(36.6 \%)$ & 0.4 \\
\hline Absent n $(\%)$ & $56(55.4 \%)$ & $19(63.4 \%)$ & \\
\hline
\end{tabular}

PCOS group: patients with polycystic ovary syndrome group; DP: standard deviation; IMC: body mass index; OGTT: oral glucose tolerance test; SBP: systolic blood pressure; DBP: diastolic blood pressure; MAP: mean arterial pressure; NCEP/ATP III: National Cholesterol Education Program/Adult Treatment Panel III; IDF: International Diabetes Association. 
group, showed higher weight, higher BMI and greater waist circumference. Patients with PCOS showed worse levels of HDL when compared with the control group. Moreover, as higher levels of insulin were showed, patients from the first group had a higher HOMA index than the second group. Regarding the prevalence of the MS diagnosis (NCEP/ATP III and IDF criteria), there was no difference between the analyzed groups.

PCOS and control groups were also compared in regard to the NAFLD prevalence (Table 2). PCOS group were diagnosed with NAFLD by ultrasonography in $23.8 \%$ of the patients, which is significantly higher than the prevalence of $3.3 \%$ in the control group.

TABLE 2. Comparison of the prevalence of non-alcoholic fatty liver disease between patients with polycystic ovary syndrome group and control group

\begin{tabular}{lccc}
\hline & $\begin{array}{c}\text { PCOS group } \\
(\mathbf{n}=101)\end{array}$ & $\begin{array}{c}\text { Control group } \\
(\mathbf{n}=30)\end{array}$ & $P$ \\
\hline NAFLD & & & \\
Present n (\%) & $24(23.8 \%)$ & $1(3.3 \%)$ & 0.01 \\
Absent n (\%) & $77(76.2 \%)$ & $28(96.7 \%)$ & \\
\hline
\end{tabular}

NAFLD: non-alcoholic fatty liver disease; PCOS group: polycystic ovary syndrome group.
Finally, patients with PCOS were divided into other two groups: PCOS with NAFLD and isolated PCOS. The groups were compared according to the same clinical and laboratorial criteria from Table 1 . In this case, Table 3 shows that patients with NAFLD are older than the second group, in addition to having greater severity in almost all criteria defined for MS. They have greater weight, BMI, waist circumference, higher OGTT blood glucose, higher levels of triglycerides and a more severe hyperinsulinemia. Thus, it is understood why these patients showed higher HOMA index and higher prevalence of PCOS, regardless of the used criteria, when compared to patients without liver disease.

\section{DISCUSSION}

Published studies regarding the association between PCOS and NAFLD are still very scarce and recent and they evaluate populations with lifestyle and genetic background different from the Brazilian population ${ }^{(7)}$. One of these studies applied PCOS diagnostic criteria in 14 women with NAFLD, finding a prevalence of $71 \%$ in this population ${ }^{(25)}$.

In agreement with the literature, our results correlate the metabolic syndrome with the polycystic ovary syndrome. It is seen that patients with PCOS, although not

TABLE 3. Comparison between patients with polycystic ovary syndrome and non-alcoholic fatty liver disease sub-group with patients only with polycystic ovary syndrome sub-group

\begin{tabular}{|c|c|c|c|}
\hline & Sub-group PCOS+NAFLD $(n=24)$ & Sub-group PCOS $(n=77)$ & $P$ \\
\hline Age (years) $\pm \mathrm{DP}$ & $28.6 \pm 5$ & $26.2 \pm 5$ & 0.03 \\
\hline Weight $(\mathrm{kg}) \pm \mathrm{DP}$ & $89.3 \pm 18$ & $69.8 \pm 18$ & $<0.01$ \\
\hline $\mathrm{BMI}\left(\mathrm{kg} / \mathrm{m}^{2}\right) \pm \mathrm{DP}$ & $34.2 \pm 5$ & $26.7 \pm 5$ & $<0.01$ \\
\hline Waist circumference $(\mathrm{cm}) \pm \mathrm{DP}$ & $106.7 \pm 12$ & $86.9 \pm 14$ & $<0.01$ \\
\hline \multicolumn{4}{|l|}{ Oral glucose tolerance test } \\
\hline Fasting glucose $(\mathrm{mg} / \mathrm{dL}) \pm \mathrm{DP}$ & $100.6 \pm 7$ & $86.9 \pm 7$ & $<0.01$ \\
\hline Blood glucose after 2 hours $(\mathrm{mg} / \mathrm{dL}) \pm \mathrm{DP}$ & $121.9 \pm 27$ & $106.1 \pm 27$ & $<0.01$ \\
\hline Area under the curve OGTT & $1446.7 \pm 200$ & $1301.4 \pm 211$ & $<0.01$ \\
\hline Triglycerides $(\mathrm{mg} / \mathrm{dL}) \pm \mathrm{DP}$ & $155.5 \pm 83$ & $87 \pm 40$ & $<0.01$ \\
\hline $\mathrm{HDL}(\mathrm{mg} / \mathrm{dL}) \pm \mathrm{DP}$ & $41.7 \pm 8$ & $46.8 \pm 11$ & 0.06 \\
\hline $\mathrm{SBP}(\mathrm{mmHg}) \pm \mathrm{DP}$ & $118.2 \pm 13$ & $115.3 \pm 13$ & 0.2 \\
\hline $\mathrm{DBP}(\mathrm{mmHg}) \pm \mathrm{DP}$ & $76.2 \pm 12$ & $74.5 \pm 12$ & 0.4 \\
\hline $\mathrm{MAP}(\mathrm{mmHg}) \pm \mathrm{DP}$ & $141.3 \pm 16$ & $125.9 \pm 13$ & $<0.01$ \\
\hline Insulin $(\mu \mathrm{UI} / \mathrm{mL}) \pm \mathrm{DP}$ & $18.5 \pm 10$ & $10.3 \pm 9$ & $<0.01$ \\
\hline $\mathrm{HOMA} \pm \mathrm{DP}$ & $4.6 \pm 2$ & $2.4 \pm 2$ & $<0.01$ \\
\hline \multicolumn{4}{|l|}{$\begin{array}{l}\text { Metabolic syndrome } \\
\text { (NCEP/ATP III criterion) }\end{array}$} \\
\hline Present $\mathrm{n}(\%)$ & $75 \%$ & $19.5 \%$ & $<0.01$ \\
\hline Absent $\mathrm{n}(\%)$ & $25 \%$ & $80.5 \%$ & \\
\hline \multicolumn{4}{|l|}{$\begin{array}{l}\text { Metabolic syndrome } \\
\text { (IDF criterion) }\end{array}$} \\
\hline Present $(\%)$ & $95.8 \%$ & $28.6 \%$ & $<0.01$ \\
\hline Absent $\mathrm{n}(\%)$ & $4.2 \%$ & $71.4 \%$ & \\
\hline
\end{tabular}

PCOS+NAFLD sub-group: patients with non-alcoholic fatty liver disease sub-group associated to the polycystic ovary syndrome; PCOS sub-group: patients only with polycystic ovary syndrome sub-group; PD: pattern deviation; BMI: body mass index; OGTT: oral glucose tolerance test; SBP: systolic blood pressure; DBP: diastolic blood pressure; MAP: mean arterial pressure; NCEP/ ATP III: National Cholesterol Education Program/Adult Treatment Panel III; IDF: International Diabetes Association. 
presenting a higher MS incidence, have hyperinsulinemia, overweight, increase of the waist circumference and already start to present lipoprotein alterations. Insulin resistance is a common pathogenic mechanism of these two entities, and so it is expected that these women, if not monitored and treated, can develop MS, and even NAFLD, in the future.

Once the patients have NAFLD, the worst scores in virtually all the MS defining criteria are expected. However, it should be remembered that NAFLD itself is already a cardiovascular risk factor alone, and the assistant physician should not, thus, wait changes in glucose or lipids levels to begin treatment.
It is expected that the physician, especially, the gynecologist, watches not only for the reproductive and esthetic effects, but especially for the metabolic and liver consequences of PCOS.

Further studies to answer if it is valid to monitor all patients with PCOS for non-alcoholic fatty liver disease would be important for future references.

\section{Authors' contributions}

Romanowski MD: data collection and writing of text. Parolin MB: writing of text, hepatology consultant. Freitas ACT: statistical analisys. Piazza MJ: writing of text. Basso J: ultrassound operator. Urbanetz AA: data collection, writing of text, supervision.

Romanowski MD, Parolin MB, Freitas ACT, Piazza MJ, Basso J, Urbanetz AA. Prevalência de doença hepática gordurosa não alcoólica em pacientes com síndrome dos ovários policísticos e sua correlação com síndrome metabólica. Arq Gastroenterol. 2015,52(2):117-23.

RESUMO - Contexto - A síndrome dos ovários policísticos (SOP) é um dos distúrbios endócrinos mais comuns nas mulheres na idade fértil. A síndrome metabólica está presente em $28 \%$ a 46\% das pacientes com SOP. A doença hepática gordurosa não alcoólica (DHGNA) é considerada a expressão hepática da síndrome metabólica. Existem poucos estudos publicados da associação SOP e DHGNA. Objetivos - Determinar a prevalência de DHGNA e síndrome metabólica em portadoras de SOP, verificar se existe correlação entre a ocorrência de DHGNA e síndrome metabólica nessa população. Métodos - Estudo realizado no Ambulatório de Ginecologia do Hospital de Clínicas da Universidade Federal do Paraná. O período de estudo foi de abril 2008 a janeiro de 2009. Participaram da análise 131 pacientes, sendo 101 com SOP e 30 controles. Subdividimos as pacientes com SOP em dois subgrupos: SOP+DHGNA e SOP. Todas foram submetidas a exame ultrassonográfico do fígado. Para rastreamento da esteatose hepática, a ecotextura do parênquima hepático foi comparada com a do baço. Para do diagnóstico da síndrome metabólica foram adotados os critérios propostos pelo National Cholesterol Education Program/Adult Treatment Panel III (NCEP/ATP III) e do International Diabetes Federation. A análise estatística foi feita com teste $t$ de student e U de Mann-Whitney para medias e qui-quadrado para proporções. Resultados - No grupo com SOP, a DHGNA esteve presente em $23,8 \%$ da população. No grupo controle, isso ocorreu em 3,3\%, com diferença estatística $(P=0,01)$. A síndrome metabólica pelos critérios NCEP/ATP III, esteve presente em 32,7\% no grupo SOP e 26,6\% no grupo controle (sem diferença estatística $P=0,5$ ). No subgrupo SOP+DHGNA, a idade, o peso, IMC, circunferência abdominal e teste de tolerância à glicose foram maiores quando comparados ao grupo $\operatorname{SOP}(P<0,01)$. A síndrome metabólica pelo critério NCEP/ATPIII esteve presente em $75 \%$ e pelo International Diabetes Federation em $95,8 \%$ no grupo SOP+DHGNA com $P<0,01$. O nível de Insulina no grupo SOP+DHGNA foi maior que no grupo SOP com $P<0,01$. Conclusãa - Próximo a $25 \%$ das pacientes com SOP foram diagnosticadas com DHGNA. A síndrome metabólica esteve presente entre 32,7\% a 44,6\% nas pacientes com SOP. No Subgrupo SOP+DHGNA a síndrome metabólica é altamente prevalente. São pacientes mais obesas, com IMC maior e com níveis glicémicos também maiores.

DESCRITORES - Síndrome do ovário policístico. Fígado gorduroso. Síndrome X metabólica. 


\section{REFERENCES}

1. Apridonidze T, Essah PA, Iuorno MJ, Nestler JE. Prevalence and characteristics of the metabolic syndrome in women with polycystic ovary syndrome. J Clin Endocrinol Metabol. 2005;90(4):1929-35.

2. Azziz R, Carmina E, Dewailly D, Diamanti-Kandarakis E, Escobar-Morreale HF, Futterweit W et al. Positions statement: criteria for defining polycystic ovary syndrome as a predominantly hyperandrogenic syndrome: an Androgen Excess Society guideline. J Clin Endocrinol Metabol. 2006;91(11):4237-45.

3. Azziz R, Woods KS, Reyna R, Key TJ, Knochenhauer ES, Yildiz BO. The prevalence and features of the polycystic ovary syndrome in an unselected population. J Clin Endocrinol metabol. 2004;89(6):2745-9.

4. Biyasheva A, Legro RS, Dunaif A, Urbanek M. Evidence for association between polycystic ovary syndrome (PCOS) and TCF7L2 and glucose intolerance in women with PCOS and TCF7L2. J Clin Endocrin Metab. 2009;94(7):2617-25.

5. Brzozowska MM, Ostapowicz G, Weltman, MD. An association between non-alcoholic fatty liver disease and polycystic ovarian syndrome. J Gastroenterol Hepatol. 2009;24(2):243-7.

6. Carmina E, Napoli N, Longo RA, Rini GB, Lobo RA. Metabolic syndrome in polycystic ovary syndrome (PCOS): lower prevalence in southern Italy than in the USA and the influence of the criteria for the diagnosis of PCOS. Eur J Endocrinol. 2006;154(1):141-5.

7. Cerda C, Pérez-Ayuso RM, Riquelme A, Soza A, Villaseca P, Sir-Petermann T, et al. Nonalcoholic fatty liver disease in women with polycystic ovary syndrome. J Hepatol. 2007;47(3):412-7.

8. Charatcharoenwitthaya P, Lindor KD. Role of Radiologic Modalities in the Management of Non-alcoholic Steatohepatitis. Clin Liver Dis 2007;11(1): 37-54.

9. Dokras A, Bochner M, Hollinrake E, Marklam S, VanVoorhis B, Jagasia DH. Screening women with polycystic ovary syndrome for metabolic syndrome. Obstet gynecol 2005;106(1):131-7.

10. Edmison J, McCullough AJ. Pathogenesis of non-alcoholic steatohepatitis: human data. Clin Liver Dis. 2007;11(1):75-104

11. Ehrmann DA. Polycystic ovary syndrome. N Engl J Med. 2005;352(12):1223-6.

12. Ehrmann DA, Barnes RB, Rosenfield RI, Cavaghan MK, Imperial J. Prevalence of impaired glucose tolerance and diabetes in women with polycystic ovary syndrome. Diabetes Care. 1999;22(1):141-6.

13. Franks S. Polycystic ovary syndrome. N Eng J Med. 1995;333(13):853-61

14. Gambarin-Gelwan M, Kinkhabwala SV, Schiano TD, Bodian C, Yeh HC, Futterweit W. Prevalence of nonalcoholic fatty liver disease in women with polycystic ovary syndrome. Clin Gastroenterol Hepatol. 2007;5(4):496-501.
15. Grundy SM, Cleeman JI, Daniels SR, Donato KA, Eckel RH, Franklin BA, et al. American Heart Association; National Heart, Lung, and Blood Institute: Diagnosis and management of the metabolic syndrome: An American Heart Association/National Heart, Ling and Blood Institute scientific statement. Circulation 2005;112(17):2735-52.

16. Knochenhauer ES, Key TJ, Kahsar-Miller M, Waggoner W, Boots FR, Azziz $\mathrm{R}$. Prevalence of the polycystic ovary syndrome in unselected black and white women of the southeastern United States: a prospective sutdy. J Clin Endocrinol Metabol. 1998;83(9):3078-82.

17. Legro RS, Kunselman AR, Dodson WC, Dunaif A. Prevalence and predictors of risk for type 2 diabetes mellitus and impaired glucose tolerance in polycystic ovary syndrome: A prospective, controlled study in 254 affected women. J Clin Endocrinol Metabol. 1999;84(1):165-9.

18. Marchesini G, Marzocchi R. Metabolic syndrome and NASH. Clin Liver Dis 2007;11(1):105-17.

19. Marcondes JAM, Hayashida SAY, Barcellos CRG, Rocha MP, Maciel GAR, Baracat EC. Metabolic syndrome in womem with polycystic ovary syndrome: prevalence, characteristics and predictors. Arq Bras Endocrinol Metabol. 2007;51(6):972-9.

20. Mather KJ, Hunt AE, Steinberg HO, Paradisi G, et al. Repeatability characteristics of simple indices of insulin resistence: implications for research applications. J Clin Endocrinol Metabol. 2001;86(11):5456-464.

21. Olufadi R, Byrne CD. Clinical and laboratory diagnosis of the metabolic syndrome. J Clin Pathol. 2008; 61(6):697-706.

22. Ong JP, Younossi ZM. Epidemiology and natural history of NAFLD and NASH. Clin Liver Dis. 2007;11(1):1-16.

23. Pfeifer SM, Kives S. Polycystic ovary syndrome in the adolescent. Obstet Gynecol Clin North Am. 2009;36(1):129-52.

24. Rotterdam ESHRE/ASRM-Sponsored PCOS Consensus Workshop Group. Revised 2003 consensus on diagnostic criteria and long-term health risk related to polycystic ovary syndrome. Fertil Steril. 2004;81(1):19-25.

25. Sejti TL, Holland ND, Sanders LL, Pereira KC, Diehl AM, Brown AJ. Nonalcoholic steatohepatitis and nonalcoholic fatty liver disease in young women with polycystic ovary syndrome. J Clin Endocrinol Metb. 2006;91(5):1741-47.

26. Srikanthan P, Korenman S, Davis S. Polyciystic ovarian syndrome: the next cardiovascular dilemma in women? Endocrinol Metab Clin North Am. 2006;35(3):611-31.

27. The IDF consensus wordlwide definition of metabolic syndrome. Available from: http://www.idf.org.

28. Rotterdam ESHRE/ASRM-Sponsored PCOS Consensus Workshop Group. Revised 2003 consensus on diagnostic criteria and long-term health risk related to polycystic ovary syndrome. Hum Reprod. 2004;19:41-7. 